European journal of American studies

Special Issue: Women in the USA

\title{
Introduction: North American Women in Politics and International Relations
}

\section{Isabelle Vagnoux}

\section{(2) OpenEdition \\ Journals}

Electronic version

URL: https://journals.openedition.org/ejas/10463

DOI: 10.4000/ejas. 10463

ISSN: 1991-9336

Publisher

European Association for American Studies

\section{Electronic reference}

Isabelle Vagnoux, "Introduction: North American Women in Politics and International Relations", European journal of American studies [Online], 10-1 | 2015, document 1.1, Online since 26 March 2015, connection on 08 July 2021. URL: http://journals.openedition.org/ejas/10463 ; DOI: https://doi.org/ 10.4000/ejas. 10463

This text was automatically generated on 8 July 2021.

Creative Commons License 


\title{
Introduction: North American Women in Politics and International Relations
}

\author{
Isabelle Vagnoux
}

1 "We can't be more machista than the Argentines," former President Bill Clinton reportedly quipped in 2008, when his wife Hillary Rodham Clinton was battling in the Democratic primaries of the presidential election, shortly after Cristina Fernandez de Kirchner had been elected President of Argentina in 2007, and following Michelle Bachelet's election in Chile the year before. The United States more 'machista' than Latin America in politics ? A challenging issue that was tackled during the French Institute of the Americas' annual conference, December 4-6, 2013, which gathered over 150 scholars working on Women in the Americas at Aix-Marseille Université, France. The selection that follows was part of a panel devoted to Women, politics and international relations in the Americas. Only those focusing on the United States and Canada are presented in this issue of the European Journal of American Studies. While four pieces are devoted to a variety of aspects of women's representation and influence in politics, three others focus on American women in international relations or diplomacy.

\section{Of underrepresentation}

2 Empirical research and statistics show indeed that the United States is not faring very well in terms of women's political representation and influence although significant nuances may exist between the local, state and national levels. As of August 2014, the Interparliamentary Union ranks the United States 86th out of 152 with a meagre $18.2 \%$ in 
terms of representation in the federal lower house of Congress ${ }^{i}$ while representation in the upper House is slightly better with $20 \%$. As compared with 1997, figures have improved (11.7\% for the U.S. lower House and 9\% for the Senate) but at the time, the United States ranked 39th. In other words, many countries have significantly done better than the U.S. in the course of the past seventeen years. Canada now ranks 55th, with $25.1 \%$ in the lower house, but fares much better in the upper house, with a $39.6 \%$ representation, which would place it within the 25-28 ranks bracket, if representation in upper houses were taken into account. Back in 1997 it was ranking 17th with respectively $20.6 \%$ and $23.1 \%$. With this record the United States is doing worse than most nations in the Western Hemisphere. Only Venezuela (89th), Chile (95th) -an anomaly given the election, twice, of a woman president, Michelle Bachelet, and an equal gender proportion in her government) - Paraguay (98th), Guatemala (107th), Uruguay (109th), Brazil (131st, another anomaly in view of the election, twice, of a woman President, Dilma Rousseff), Haiti (142nd) show poorer results. Ironically, Cuba ranks third in this classification, with a $48.9 \%$ rate of female representation in its one-house parliament. Given the nature of the Cuban regime, this good ranking does not allow to make the democratic practices/female representation a systematic link, although Nordic European countries all rank in the first sixteen nations and confirm the validity of this link. ${ }^{\text {ii }}$

3 Part of the reasons for such comparatively mediocre results might be the ambivalence of public opinion which does not perceive women's rights as a priority, still inferior fundraising, ,ii $^{\text {ii }}$ or difficulty in juggling family and political lives. In this respect the formidable careers of some high profile and role-model women - appointed orelected- (former Secretaries of State Madeleine Albright, Condoleezza Rice, Hillary Clinton, former Attorney General Janet Reno, former Speaker of the House Nancy Pelosi, as well as candidates for the US vice-presidency or presidency Geraldine Ferraro, Sarah Palin or Michelle Bachman, to name but a few) tend to hide the obstacles that still make it difficult for women to get elected or to hold high-ranking positions. Another reason is the lack of structural guarantees such as equal rights or legislated quotas for women in nationwide elections. While such quotas have significantly improved the representation of women in most Latin American countries in recent years, they do not exist in the United States and in Canada. Canada however implements voluntary political party quotas, like many countries in Europe, but the U.S. offers no incentive at all.iv The first piece of this selection, by Chantal Maillé, examines the role of women's movements and some of the initiatives launched over the last 25 years to counter the problem of low numbers of elected women in Canadian and American parliaments, and precisely emphasizes the absence of mobilization in favor of legal quotas.

4 The relatively feeble and very uneven rate of women representation at the state and local levels is both a source of preoccupation and a 
source of hope. A source of hope because these rates jumped significantly and incrementally between 1975 and today. As far as state legislatures are concerned, they increased from $2.5 \%$ to $26.7 \%$ in California, from $4.3 \%$ to $21.1 \%$ in New York, to name but a few. Even Louisiana, the laggard in the U.S. class, improved from $1.4 \%$ to $12.5 \%$. At the other end of the spectrum, the best states are Colorado (41\%) and Vermont with a $40.6 \%$ rate in 2014 but not a single woman representing it in the U.S. Congress. ${ }^{v}$ It is also source of preoccupation however, as in most states these figures still lag well below the eligible proportion of women in the population. Worse still, women's representation in statewide elected executive office appears to be declining after the highs of the late 1990's. The all-time high was reached in 2000 , with $28,5 \%$, and steadily declined ever since, reaching only $22.6 \%$ in 2014 . ${ }^{\text {vi }}$ Five women (10\%) serve as governors as of 2014 : four Republicans and one Democrat. Altogether, 35 women (20 Democrats and 15 Republicans) have served as governor in U.S. history, in 26 states. At the local level, $18.4 \%$ of cities over 30,000 are headed by women mayors, including some large ones such as Houston. ${ }^{\text {viiA }}$ similar ratio is to be found for Presidential Cabinet appointments. To date, women hold $23 \%$ of Presidential Cabinet or Cabinet-level positions, a ratio that has slowly but steadily increased, term after term, since the $11 \%$ held by women in the period from F.D. Roosevelt to Kennedy. ${ }^{\text {vii }}$

5In spite of incremental progress, women's underrepresentation continues in American politics, in a country which defeated the Equal Rights amendment in 1982 after a ten-year struggle to get enough states to ratify it. ${ }^{\text {ix }}$ However, according to political scientist Jane Mansbridge, the ERA struggle brought about a number of positive results: ${ }^{\mathrm{x}}$ it made the public aware of women's rights on a long-term basis (although the jurist Deborah Rhode argues that perceptions of inequality in leadership opportunities are never pervasive); ${ }^{\mathrm{xi}}$ in addition, the ten-year ERA campaign brought many women into the political process, whether for or against the amendment. As a natural consequence, many of these women continued their political paths by running in elections and were supported by women's rights organizations and PACs. This is why Jane Mansbridge views Geraldine Ferraro's nomination as the Democratic vice-presidential candidate in 1984 as a direct consequence of the ERA campaign. The fact that today a majority of women candidates at all levels are liberals also derives from the ERA struggles of the 1960's and 1970's.

\section{Women and political movements}

6 When the federal campaign laws were changed in 1974 and allowed for the creation of political action committees (PACs) to give money directly to political candidates, several were immediately created to bring financial support to women candidates. As of 2014, some 70 PACs 
for women candidates or whose donors are mainly women are recorded at the national or state levels.xii While the largest PAC, EMILY's List, supports pro-choice Democratic women, a number of Republican PACs were funded to support Republican women candidates, with or without an interest in the pro/anti-choice issue. The Susan B. Anthony List has now become one of the main conservative-leaning, pro-life PACs. Like other conservative PACs and advocacy groups, it aims to challenge feminist claims and offers a different approach to politics by women who contest feminist and liberal interpretations of what American women's interests are. Conservative PACs, however, still lag behind liberal ones due to two main reasons: their shorter experience as most of them were born recently; and less support-so far- from the Republican Party, hence lower fundraising levels. For instance, in 2014, while the liberal Super PAC Women Vote! raised $\$ 12,397,254$, the conservative Women Speak Out only raised \$3, 684,634. ${ }^{\text {iii }}$

7 Republicans and Democrats have taken turns in electing more women in statewide elected offices, and have come to reach a nearly equal number since 2012. However, while Republicans have recorded higher success in governorships (4 v. 1 in 2014), the Democratic party shows a much better scorecard, returning a much larger proportion of women to state legislatures $(63.6 \%$ v. $35.7 \%$ in 2014$)$ and to the U.S. Congress (16\% v. $4 \%$ in the Senate, and $14 \%$ v. $4 \%$ in the House in 2014.) ${ }^{\text {xiv }}$ While liberals may have had a better known impact on public opinion and have probably been more widely studied, conservative women also have played a prominent role in shaping conservative networks, challenging feminist claims, and disseminating right-wing political ideas, whether related to women's issues or not.

8 Two contributions in this volume focus on women and conservatism, although not specifically on the Republican party. Florence Kaczorowski goes back to the 1950's with the Vigilant Women for the Bricker Amendment Movement. Although right-wing women had been active in the United States prior to this period, this piece shows how "resurgent domesticity shaped these women's activism" and emphasizes the role played by these women in disseminating anti-internationalist ideas and activating a large grassroots network around a single issue. Although this movement came to naught as the Bricker amendment eventually failed in Congress, their action contributed to mobilizing conservative women and getting them involved in politics. Sébastien Mort focuses on a more recent aspect of conservatism and analyzes conservative radio talk shows, particularly The Rush Limbaugh Show and The Laura Ingraham Show, as well as the relationship between female callers and hosts. His analysis emphasizes that female hosts in these shows are a rarity and female callers grossly underrepresented. However, differences can be perceived between the man host who appears as custodian of the traditional gender order, and the woman host who "recalibrates gender relationships in a way that is as favorable to 
women as it is to men, thus allowing conservatism to redefine its stance on gender equality."

\section{A place to find for themselves: BETWEEN INVISIBILITY AND PROMINENCE}

9 The selection that follows, with the article by Pierre-Marie Loizeau, also approaches the Women and Politics theme from the angle of the First Ladies, a field that has only recently received close scholarly attention. Although devoid of any constitutional existence and any official function, First Ladies paradoxically count among the most prominent American public figures. The trend towards highly visible First Ladies started with Eleanor Roosevelt and was brought to unprecedented highs by Hillary Clinton. Both of them were also the most criticized. Research conducted by pollsters indeed highlights that Americans, women and men, young and old, "seem to be most comfortable with spouses who embrace traditional gender roles, " hence the very high ratings obtained by Barbara Bush and Laura Bush during their husbands' presidential campaigns, with respectively $88 \%$ and $83 \% .^{x v}$ This is also one of the conclusions reached by Pierre-Marie Loizeau's piece, "the more power Presidential wives seem to wield, the lower their popularity." After Hillary Clinton, the next First Ladies cautiously steered clear of controversial issues and emphasized their motherhood. This was particularly obvious with Michelle Obama, who had a high-profile career prior to her husband's election as President. Beyond approval ratings, their role remains one of great ambiguity. Although some observers have coined the word 'co-presidency' to describe the presidential couple, it appears that so far First Ladies' public role remains closer to joint image-making than power-sharing.

\section{WOMEN IN INTERNATIONAL RELATIONS}

10 Comparatively little so far has been published on gender and diplomatic relations. Women were permitted to join the diplomatic corps in 1922. The first female chief of mission, Ruth Bryan Owen, was appointed in 1933, during the F.D. Roosevelt presidency that also allowed the nomination of the first woman to a Cabinet position, Frances Perkins. The first woman ambassador was only appointed in 1949 (to Denmark) and only a handful of women were appointed at that level for several decades. Real progress did not come before the Carter Administration with the appointment of eighteen women as chiefs of mission and ten in senior positions in Washington. The number of appointments doubled under Presidents Reagan and George H. Bush and sky-rocketed under the Clinton Administration before reaching a plateau under his successors. ${ }^{\text {xvi }}$ Yet, according to Council on Foreign Relations expert Micah Zenko, despite the presence of role models such as Hillary Clinton, Susan Rice or Samantha Power, women remain 
grossly underrepresented, especially at the highest levels of policy making, which affects diversity in ideas and policy orientations. Radical feminists, as well as historian Francis Fukuyama who champions a biological perspective, go further and argue that the larger presence of women at the policy-making level would produce a safer and more peaceful world.xvii Only $22 \%$ of senior leaders at the State Department and $29 \%$ of the chiefs of mission at U.S. embassies are women. Zenko found similar proportions in his survey of think tanks with a substantial foreign policy focus, with women making up $21 \%$ of the policy-related positions and $29 \%$ of the total leadership staff. xvii Similarly, while women make up $46 \%$ of the CIA's workforce, they only make up $31 \%$ of the Senior Intelligence Service. ${ }^{\text {xix }}$

11 Women's rights and issues has also become a growing focus of attention in the State Department, particularly under Secretary Hillary Clinton, who made it one of her priorities. An ambassadorship at large for global women's issues was thus created in 2009 to weave the perspective of women's issues "even deeper into the fabric of American foreign policy" and to affirm the link between women's rights and national security. "It is no coincidence that so many of the countries that threaten regional and global peace are the very places where women and girls are deprived of dignity and opportunity," Clinton added at the Fourth Women in the World Summit, April 5, 2013. Whether this focus will be maintained under less committed future Secretaries of States or whether it is Hillary Clinton's work exclusively is still an open question.

12 The last three contributions of this selection focus on the place and influence of women in international relations, either as active officials (diplomats), or unofficial agents (wives) or objects of U.S. policies abroad. Two pieces focus on the U.S. Foreign Service. Molly M. Wood analyzes the debates, in the State Department and among American diplomats abroad, about the roles of women as wives, clerks and professional diplomats in the U.S. Foreign Service in the 1900-1940 era, while Beatrice McKenzie, through the case study of Alison Palmer, a U.S. Foreign Officer from 1959 to 1981, argues that the "sexualization of women officers in the 1960's and 1970's led to less rather than more gender equality among Foreign Service Officers."

13 The last piece, by Fatma Chehih-Ramdani, although not dealing with official diplomats but rather with internationalist women militants such as Mary Church Terrell, Mary McLeod Bethune and Amy Jacques Garvey, shows how these African American women at a very early stage of the 20th century used international conferences and congresses to forward the claims of people of color in the United States, and thus paved the way for diversity in the U.S. Foreign Service Corps and modern diplomacy. 


\section{Conclusion: "The Unfinished business of the 21 st century"}

14 To conclude this introductory piece, whether in domestic politics, foreign relations, defense or intelligence, the pattern in the 21st century appears to be one of clear improvement in the presence of women as compared to the 1960's and earlier times, with a multiplication of high-ranking women who act as role-models and a wider awareness of women's rights across the nation. Yet the glass ceiling is still very much present. Due to a conjunction of factors such as insufficient fundraising, unequal interest in the political parties, remnants of discrimination, as well as the difficulty to reconcile family and political lives, women at best constitute hardly more than a quarter of the policy-making positions in the United States, while according to the Bureau of the Census they make up $50.8 \%$ of total population. In Hillary Clinton's words, "this is truly the unfinished business of the 21 st century." xx

\section{NOTES}

i. Interparliamentary Union, "Women in National Parliaments", August 2014, http:// www.ipu.org/wmn-e/classif.htm (accessed August 25, 2014).

The decision to take only lower houses into account for classification purposes originates in the absence of upper houses in a number of countries.

ii. Such smaller nations as Barbados, Saint Lucia, Bahamas, Jamaica, Saint Vincent and the Grenadines, Dominica, Suriname, Antigua \& Barbuda, Saint Kitts \& Nevis, Belize all rank lower than the U.S.

iii. On this specific issue, see the most interesting report jointly published by the National Council for Research on Women, the Rutgers Center for American Women and Politics, and the Center for Responsive Politics, “Money in Politics With A Gender Lens", January 2014, http:// regender.org/sites/ncrw.org/files/moneyinpoliticswithagenderlens_0.pdf, (accessed December $7,2014)$ as well as the She Should Run report "Vote With Your Purse. Lesson Learned: Women, Money, and Politics in the 2010 Election Cycle", April 2012. http:// d3n8a8pro7vhmx.cloudfront.net/womenandpolitics/pages/50/attachments/original/

1378712276/vote-with-your-purse.pdf?1378712276 (accessed December 7, 2014)

iv. Global Database of Quotas for Women, http://www.quotaproject.org/uid/countryview.cfm? (accessed August 22, 2014)

v. Center for American Women and Politics (hereafter CAWP), National Information Bank on Women in Public Office, Eagleton Institute of Politics, Rutgers University. "Women in State Legislatures", http://www.cawp.rutgers.edu/fast_facts/resources/state_fact_sheet.php\#states , "Fact Sheets on Women in State Legislatures" http://www.cawp.rutgers.edu/fast_facts/ levels_of_office/documents/stleg.pdf (accessed August 22, 2014) 
vi. CAWP, "Statewide Elective Executive Office Women" http://www.cawp.rutgers.edu/ fast_facts/levels_of_office/documents/stwidehist.pdf (accessed November 27, 2014)

vii. CAWP, Election Watch, November 5, 2014, “2014 : Not A Landmark Year for Women, Despite Some Notable Firsts", http://www.cawp.rutgers.edu/press_room/news/documents/ PressRelease_11-05-14-electionresults.pdf (accessed November 27, 2014)

viii. CAWP, "Women appointed to Presidential Cabinets" http://www.cawp.rutgers.edu/ fast_facts/levels_of_office/documents/prescabinet.pdf (accessed November 27, 2014)

ix. Joyce Gelb, Marian Lief Palley, ed., Women and Politics around the World. A Comparative History and Survey (Santa Barbara : ABC-CLIO, 2009), 649.

x. Jane J. Mansbridge, Why We Lost the ERA (Chicago : University of Chicago Press, 1986).

xi. Deborah Rhode, ed., The Difference 'Difference' Makes : Women and Leadership (Palo Alto, CA : Stanford University Press, 2002), 6.

xii. CAWP, “Women's PACs and Donor Networks", August 2014, http://www.cawp.rutgers.edu/ education_training/resources/documents/pacs.pdf (accessed December 6, 2014)

xiii. Center for Responsive Politics, "Super PACs", http://www.opensecrets.org/pacs/ superpacs.php?cycle=2014 (accessed December 6, 2014)

xiv. CAWP, "Women in State Legislatures" ; National Conference of State Legislatures, "Women in State Legislatures for 2014", April 2014, http://www.ncsl.org/legislators-staff/legislators/ womens-legislative-network/women-in-state-legislatures-for-2014.aspx (accessed December 6, 2014)

xv. Barbara Burrell, Laurel Helder, Brian Frederick, "From Hillary to Michelle : Public Opinion and the Spouses of Presidential Candidates", Presidential Studies Quarterly 41, n²1, March 2011, $163,174$.

xvi. American Foreign Service Association, "Female U.S. ambassadors", " Ambassadorial Appointments-Jimmy Carter”, “ Ambassadorial Appointments-Ronald Reagan” “ Ambassadorial Appointments-George H. Bush" “ Ambassadorial Appointments-Bill Clinton” "Ambassadorial Appointments-George W. Bush”, http://www.afsa.org/ambassadors.aspx (accessed December 7, 2014)

xvii. Sandra Whitworth, "Feminism" in Christian Reus-Smit \& Duncan Snidal, eds., The Oxford Handbook of International Relations (Oxford: Oxford University Press, 2010), 394. Francis Fukuyama. "Women and The Evolution of World Politics", Foreign Affairs, 77, n5, SeptemberOctober 1998, 24-40.

xviii. Micah Zenko, "City of Men”, Foreign Policy, July 14, 2011, http://www.foreignpolicy.com; "Where are the Women in Foreign Policy?", Council on Foreign Relations, March 8, 2012, http:// www.cfr.org (accessed December 6, 2014)

xix. Brigid Schulte, "Many women in CIA still encounter glass ceiling, agency report says", Washington Post, June 14, 2013. CIA Women in Leadership, https://www.cia.gov/library/reports/ CIA_Women_In_Leadership_March2013.pdf (accessed December 6, 2014)

xx. Hillary Clinton's Keynote Address at the Fourth Women in the World Summit, April 5, 2013. 


\section{INDEX}

Keywords: elections, First Ladies, international relations, PACs, politics, underrepresentation, women

Mots-clés: Alison Palmer, Amy Jacques Garvey, Barbara Bush, Bill Clinton, Condoleezza Rice, Cristina Fernandez de Kirchner, Deborah Rhode, Dilma Rousseff, Eleanor Roosevelt, Frances Perkins, Francis Fukuyama, Franklin D. Roosevelt, George H. Bush, Geraldine Ferraro, Hillary Clinton, Jane Mansbridge, Janet Reno, Jimmy Carter, John F. Kennedy, Laura Bush, Madeleine Albright, Mary Church Terrell, Mary McLeod Bethune, Micah Zenko, Michelle Bachelet, Michelle Bachman, Michelle Obama, Nancy Pelosi, Ronald Reagan, Ruth Bryan Owen, Samantha Power, Sarah Palin, Susan Rice

\section{AUTHOR}

\section{ISABELLE VAGNOUX}

Aix-Marseille Université 